\title{
PROBLEMS OF CERTIFIED PATENTS IMPLEMENTATION ON THE UKRAINIAN MARKET OF INNOVATION
}

\section{Zhytar Maksym ${ }^{1}$ Ananieva Julia ${ }^{2}$}

DOI: https://doi.org/10.30525/978-9934-571-89-3_127

In the modern world, use innovations in forming the development state strategy takes the top-priority place, which can be explained by the following trends of the world economy:

- the quality of human capital is becoming an essential characteristic of global innovation development, and the mobility of highly skilled personnel ensures knowledge dissemination, contributing to increased competitiveness;

- the role of information technology in the dissemination process of knowledge is becoming more relevant for the further growth of innovation activity;

- globalization forces companies to compete at increasingly levels of technologies and at the same time stimulate the specialization and localization processes of innovations;

- the countries which realized the concept of the national innovation system (NIS) created effective innovative economies within a short historical period of time, which include mechanisms of interaction between the state, business, science and education, and to achieve an increase in the total GDP capacity of science;

- there was a share reduction of the state sector in the stabilization conditions or reduction of "state order" to science from national budgets [1].

Today in Ukraine, only a few elements of the NIS are created and operate, the cycles of the innovation process are weakly linked to each other and are not tied together, so the return on innovation is continue low. There are two main reasons of this:

- Ukraine has very few patents for inventions, only about a quarter of all applications;

- almost 20,000 patents in Ukraine are owned by foreign companies and citizens.

Exploring the Ukrainian innovation market, we can see that $60 \%$ of the patents belong to foreigners in the agro-industry, which is considered to be the "locomotive" of the Ukrainian economy. The most active were the US citizens who received in Ukraine 689 patents. EU residents filed 331 patent applications through the European Patent Office. In addition, 297 patents were received in Ukraine by citizens of Germany. Residents of Great Britain have 120 patents, while Japan - 107 [2].

Annually in Ukraine, patents related to the agrarian sector are issued up to 300 : mainly in agrochemistry and agricultural engineering. The total number of patents for 11 years has reached 3 240. For comparison, in the Netherlands where the agrarian sector of this country is one of the most innovative in the world, were issued 5548 patents during this time. In the Netherlands the agricultural crops is

\footnotetext{
${ }^{1}$ University of the State Fiscal Service of Ukraine, Ukraine

${ }^{2}$ University of the State Fiscal Service of Ukraine, Ukraine 
allocated 20 times less land than in Ukraine - a total of 1.9 million hectares. The industry employs ten times fewer people than in Ukraine. At the same time, the Netherlands exports agricultural products to 91.7 billion euros, and Ukraine 17.9 billion dollars [2].

The American firm Qualcomm in Ukraine has registered the largest number of patents -644 , which is engaged in development of wireless communication facilities and produces microprocessors. Quarterly Qualcomm spends $\$ 5.5$ billion for research and development on a global scale. And by the results of 2017, patents brought her a profit of $\$ 5.1$ billion [2].

Most Ukrainian innovations are borned at universities. The National University of Bioresources and Natural Resources of Ukraine is the patent record holder in Ukraine, which has 579 patents. Another is the National University of Food Technologies which count 405 patents and the National Mining University which has 211 patents [3].

Citizens of Ukraine have issued 5,600 patents since 2007 in foreign jurisdictions in 19 countries. Also the authors and co-authors of over 4,600 inventions spoke in other countries. The most invented with the Ukrainians is Samsung [2].

According to the report "Ukraine in the Global Innovation Dimension Report 2007-2017", presented by the Analytical Group, Ukrainian residents registered patents jointly with United States Technologies Group, an American financial and industrial group that produces aircraft engines, gas turbines, aerospace equipment, climate systems, elevators, etc. [3].

Information technologies (IT) are among the three most important sectors of the economy in Ukraine side by side with the agrarian sector and industry. IT forms in Ukraine takes about 3\% of the country's GDP for several years. The main exporters of the Ukrainian IT product are outsourcing companies which are developing software for customers from the US and Europe. According to DOU, 50 of the largest developer companies in Ukraine employ almost 40,000 technical specialists.

Particularly, the five key technologies that Ukrainians are working on are communications (400 patents). The second place is wireless technologies (261 patents), in the third place - data transmission (195 patents). Next are graphic objects (191 patents) and video processing (184 patents) [3].

The conducted researches give an opportunity to characterize the situation, which is formed on the innovative market of Ukraine, as one that promotes innovation and investment development of various industries, their structural reorganization. Ukraine still has a strong scientific and technological potential of scientists, engineers, managers, civil servants, who has developed a large amount of methodological approaches, methods, projects to accelerate the innovative development of the economy. But unfortunately, almost all developed patents in our state are transferred to the property of foreign states or citizens.

Therefore, it is necessary to use developed patents in Ukraine to solve this problem. It is advisable for the government to develop a long-term innovation strategy, which should be part of the overall economic strategy. Also, the government should return to itself the functions of the choice of priorities (the relevant documents 
defining the vector of economic development of the country should be discussed, adopted and implemented). This will give an impetus to innovation and research, as it becomes clear what should be focused on.

\section{References:}

1. Tkalenko N. V. (2015). Osoblyvosti formuvannja innovacijnogho resursu postindustrialjnykh krajin-innovatoriv [Features of formation of innovative resource of postindustrial innovation countries]. Naukovyj visnyk Polissja, vol. 2.

2. Analitychna ghrupa [Innolytics group] (2017). Ukrajina u Zviti ghlobaljnogho innovacijnogho vymiru 2007-2017. Kyiv. Retrieved from: https://www.singularityukyiv.com/wpcontent/ uploads/2018/05/UReport_finalversion_1.pdf (accessed 12 February 2019).

3. Vlasenko V. (2018). 6 nespodivanykh faktiv pro innovaciji v Ukrajini [6 unexpected facts about innovation in Ukraine]. Dim innovacij. Retrieved from: https://innovationhouse.org.ua/ statti/6-nespodivanih-faktiv-pro-innovacii-v-ukraini/ (accessed 12 February 2019).

4. Kuzheljev M.O., Zhytar M. O. (2015). Formuvannja mekhanizmu upravlinnja kredytospromozhnistju pidpryjemstva $\mathrm{v}$ umovakh innovacijnogho rozvytku ekonomiky Ukrajiny [Formation of the mechanism for managing the creditworthiness of an enterprise in conditions of innovative development of the Ukrainian economy]. Naukovyj visnyk Nacionaljnogho universytetu derzhavnoji podatkovoji sluzhby Ukrajiny (ekonomika, pravo), vol. 2, no. 69, pp. 57-62.

5. Zhytar M. O., Kuzheljev M. O. (2015). Konceptualjni zasady efektyvnosti finansovogho zabezpechennja innovacijnogho rozvytku Ukrajiny [Conceptual principles of the effectiveness of financial support of Ukraine's innovation development]. Zbirnyk naukovykh pracj uchenykh ta aspirantiv "Ekonomichnyj visnyk universytetu", pp. 14-18. 